\title{
Present Status of Subclinical Intestinal Malabsorption in the Tropics
}

\author{
J. M. FALAIYE
}

British Medical fournal, 1971, 4, 454-458

\section{Summary}

A review of the literature on subclinical intestinal disease shows its probable relevance in certain nutritional deficiencies in the indigenous residents of tropical climates. A significant incidence of intestinal disease has been defined among asymptomatic fit-looking adult Nigerians. The results of subsequent investigation into the pathogenesis of this disorder strongly point to hypoalbuminaemia as the important factor capable of producing a biochemically and histologically defined malabsorptive state leading to subnormal nutritional status among members of this community.

\section{Introduction}

It has become possible since the introduction of peroral intestinal biopsy techniques within the past 15 years to obtain intestinal biopsy specimens for studies into the form and pattern of the villi in health and disease. During the same period the newly introduced laboratory tests have permitted the confirmation and quantification of specific absorptive defects. As a result of knowledge gained through the application of these techniques, it is now well recognized that overt malabsorption, manifesting with either gastrointestinal or nutritional features, or both, may arise from a large variety of causes, inherited or acquired, as summarized by Dyer and Dawson (1968) and in a Nutrition Society symposium on malabsorption by Ingelfinger et al. (1967).

Furthermore, it has been established that intestinal malabsorption may be present in the absence of any symptoms whatsoever; this status may represent an interval of compromised function or remission in the course of an overt disease. It may also denote the endemic intestinal disease occurring in asymptomatic, healthy-looking residents of certain tropical areas; this was the subject of a series of studies that form the text of this review.

\section{Occurrence of Intestinal Abnormalities}

Sprinz et al. (1962) working in Thailand were the first to report variations in the villous pattern of asymptomatic members of the indigenous population when the biopsy appearances obtained in their studies were compared with those of specimens obtained from normal persons living in a temperate climate. The abnormalities were observed under the dissecting microscope as leaves, ridges, or convoluted villi and under the light microscope as blunted, shortened villi with hypercellularity of the lamina propria. Subsequently, this observation has been confirmed by other investigators working in different areas in the tropics (Barker et al., 1962; Banwell et al., 1964; England and O'Brien, 1966; Jeejebhoy et al., 1966; Klipstein et al., 1966; Lindenbaum et al., 1966a; Russel et al., 1966). In addition to the instances cited, similar

\footnotetext{
College of Medicine, University of Lagos, P.M.B. 12003, Lagos, Nigeria

J. M. FALAIYE, M.D., M.R.C.P., Senior Lecturer in Medicine
}

reports have emerged from more recent studies carried out in Vietnam (Colwell et al., 1968) and Mexico (Garcia, 1968).

The nature of the biopsy abnormalities described was not apparent in these studies, and periodic-acid-Schiff-stained specimens did not show any noteworthy features. Also, similar morphological changes of the intestinal mucosa have been described in a variety of clinical situations, including overt tropical sprue (Butterworth and Perez-Santiago, 1958; Chacko et al., 1961; Baker et al., 1962; Falaiye, 1970), kwashiorkor (Burman, 1965; Stanfield et al., 1965), hookworm disease in India (Tandon et al., 1966), and rosacea (Watson et al., 1965). It is clear therefore that these histological changes do not have any diagnostic significance when taken alone.

In a proportion of instances the morphological changes that were found occurred in association with impaired intestinal absorptive capacity for xylose and fat, and for vitamin $B_{12}$ in a few instances. Thus abnormalities of jejunal structure and function were demonstrable in a proportion of apparently fitlooking native residents of these tropical areas who denied any gastrointestinal symptoms. Such findings would tend to suggest a probable association between undernutrition in the tropics and widespread subclinical malabsorption

\section{Survey of D-Xylose Absorption in Nigeria}

Against this background of reports in the literature, a preliminary study from this part of tropical Africa was embarked on in 1969 in this teaching hospital. The objectives of the study were, firstly, to determine the presence of certain nutritional deficiencies and their incidence in a healthy population sample, and, secondly, to test small-intestinal capacity for D-xylose absorption.

The results of this study carried out in 39 healthy adult Nigerians showed a high prevalence of anaemia, folic acid deficiency, and hypoalbuminaemia in the presence of a significant incidence of subnormal xylose absorption in subjects tested (Falaiye, 1969).

\section{Subclinical Intestinal Disease in Nigeria}

In a follow-up study carried out in 50 apparently normal Nigerian subjects jejunal histological appearances were assessed in relation to the capacity of the small bowel to absorb xylose, fat, and folic acid. Informed consent was given by the subjects for small-intestinal biopsy. The specimens were obtained from the upper jejunum just distal to the duodeno-jejunal flexure. The villous abnormalities observed on light microscopy were graded according to severity by the criteria used by Klipstein (1964). The results showed that not one of the biopsy specimens from Nigerians could be classified as normal when compared with specimens from healthy North American subjects. The biopsy material from 40 Nigerian subjects showed $1+$ villous abnormality, consisting of broadening and slight blunting of the villi and mucosal cellular infiltration. The 10 remaining subjects had shortening as well as broadening and blunting of the villi with pronounced increase in cellularity of the lamina propria $(2+$ villous abnormality). In addition to structural changes in the mucosa, evidence of impaired absorptive capacity for xylose and folic acid was found in $24 \%$ and $35 \%$ of the subjects respectively, but no instance of steatorrhoea was encountered. 
Furthermore, the absorption values of xylose and folic acid in the present study showed good correlation with the degree of histological abnormality (Fig. 1), the mean absorption values decreasing as the severity of the jejunal lesion increased (for xylose $\mathrm{x}=33.06, \mathrm{P}<0.01, \mathrm{r}=-0.6806$ ), (for folic acid $x=33.06, P<0.01, r=-0.4271)$. Also, the relationship of folate deficiency to xylose and folic acid malabsorption is
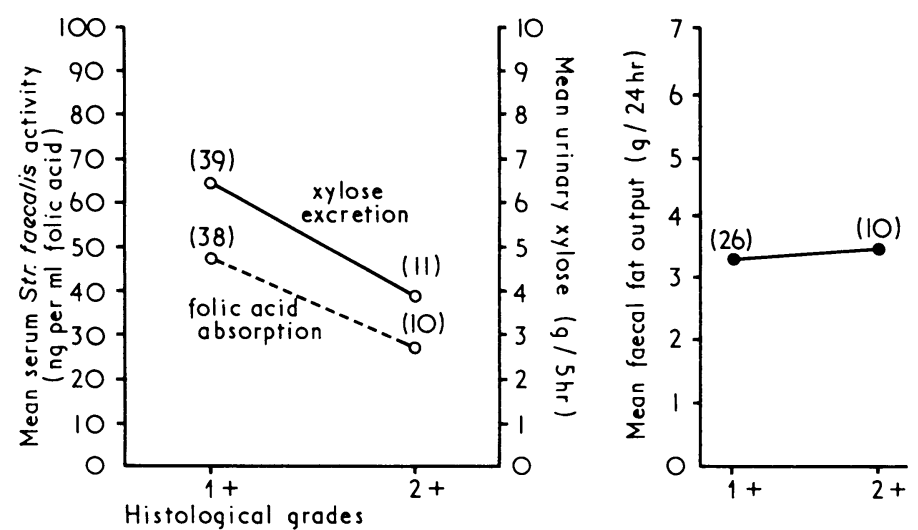

FIG. 1-Correlation of histology and absorption tests. Numbers in parentheses indicate number of specimens.

statistically highly significant (for xylose $\mathrm{P}<0.01, \mathrm{r}=0.5464$; and for folic acid $\mathrm{P}<0.01, \mathrm{r}=0.5590$ ). Thus it is deduced that in the group of folate-deficient subjects the intestinal malabsorption is probably chiefly responsible for the deficiency of folic acid.

The analyses of the data in this follow-up study showed a highly significant correlation between anaemia and folic acid deficiency on the one hand and between folate deficiency and intestinal malabsorption on the other. It is therefore reasonable to relate the endemic incidence of these haematological deficiencies among the members of this community to malabsorption from an asymptomatic small-intestinal disease, at least in part. This study has therefore established the presence of subclinical intestinal disease in Nigeria, but the aetiology of the disorder remains undetermined.

\section{Aetiological Considerations}

The aetiological considerations in subclinical intestinal disease in the tropics are discussed under the following five headings.

Ecological Factors.-Evidence has been presented by workers in India and East Africa that the villous changes observed are acquired abnormalities since the normal fingerlike villous pattern similar to the temperate pattern has been found in stillborn fetuses in these areas (Baker et al., 1962; Stanfield et al., 1965). In addition, well-nourished American Peace Corps volunteers have been shown to develop similar abnormalities of absorptive function and small-bowel morphology after a few months' exposure to tropical residence in Pakistan (Lindenbaum et al., 1966b). Similar observations have been made in Americans serving in Vietnam (Sheehy et al., 1968). The available indirect evidence also suggests that the iniestinal abnormalities which are present both in the expatriate visitors to the tropics (Lindenbaum, 1968) and in members of the indigenous population revert to normal on return to a temperate climate (Klipstein and Falaiye, 1969). It would seem probable therefore that the intestinal abnormalities in these asymptomatic subjects represent a reaction to certain environmental factors.

Infective Causes.-Lindenbaum (1965) found moderate to severe impairment of absorptive function among 95 Pakistanis who were examined during the course of an acute enteritis with a variety of identifiable enteric pathogens. During the first week after the diarrhoea had subsided three-quarters of his patients were shown to have malabsorption of xylose and vitamin $B_{12}$. Follow-up evaluation showed that the impaired absorption was transient in most cases, but was persistent for weeks or months in some, following the episode of acute bacterial enteritis. However, these individuals in Lindenbaum's studies resembled some of those described elsewhere with epidemic tropical sprue, differing only in that an identifiable enteric pathogen was demonstrable on stool culture examination. Such individuals cannot therefore be regarded as falling into the category of asymptomatic, healthy-looking residents of tropical areas with intestinal disease. It is possible, however, that subclinical malabsorption may develop as a sequela to bacterial enteritis in these instances.

Parasitic Infestations.-It has been recognized that certain parasitic infestations of the gastrointestinal tract, particularly with heavy loads of Strongyloides stercoralis (Milner et al., 1965), Ciardia lamblia (Amini, 1963), and hookworm disease in India (Tandon et al., 1966, 1969), may disrupt mucosal structure and function in the small bowel. In the two studies from Africa relating to hookworm disease and intestinal absorptive capacity Gilles et al. (1964) and Banwell et al. (1967) could not find any association between infestation with this parasite and intestinal malabsorption. It would seem therefore that the aetiological role of hookworm infestation in tropical malabsorption syndromes is still unsettled. It is pertinent to mention at this point that the association between malabsorptive state and parasitic infestations in some cases reported in the literature occurred in subjects with clinically overt intestinal disease.

"Subclinical" Tropical Sprue.-The occurrence of lesser degrees of villous morphological and functional abnormalities in association with anaemia and folate deficiency in the symptom-free control subjects in tropical-sprue-endemic areas suggests the possibility that such persons may have the disease in a subclinical form (Klipstein et al., 1966). After the studies conducted in the sprue-endemic Caribbean island of Haiti, Klipstein and others suggested that the intestinal abnormalities which they found in the asymptomatic rural inhabitants of Haiti were caused by factors similar to those responsible for the lesion in overt tropical sprue; that is to say, that subclinical intestinal disease among Haitians is subclinical tropical sprue which may at some future date become overt. This interesting hypothesis has not been followed up, however, with a view to showing tetracycline responsiveness in Haitian subiects with subclinical intestinal disease.

Dietary Inadequacies. Physiological studies have shown that there is a rapid turnover of the cells of the small-intestinal epithelium and a constant wear and tear which is met by a dynamic process of cell replacement (Leblond and Walker, 1956; Leblond and Messner, 1958). The integrity of this generative process must depend on the availablity of adequate supplies of cellular binding constituents, especially proteins, carbohydrates, and certain vitamins. Thus derangements of morphology and function might be expected to occur in the presence of sustained deficiencies of these dietary constituents and thereby contribute to the pathogenesis of subclinical intestinal disease.

\section{Aetiology of Subclinical Malabsorption}

\section{RELATION TO EXISTING DATA}

The studies previously described defined an asymptomatic small-intestinal disorder which may bear relevance to the high incidence of anaemia, folate deficiency, and hypoalbuminaemia in normally healthy-looking indigenes of Nigeria. Two subsequent studies were carried out to determine the aetiology of the condition. The first consisted of an examination of intestinal disease in its relation to certain existing data including 
small-intestinal radiological series for the detection of smallbowel anatomical defects, liver function tests and biopsies for evidence of hepatocellular dysfunction, serum albumin levels for evidence of protein nutritional status, carbohydrate tolerance tests for evidence of disaccharidase activity, and stool parasite counts for evidence of severity of parasitic infestation.

Of the 50 asymptomatic subjects studied earlier 17 were found to have malabsorption of xylose or folic acid or both in association with intestinal abnormalities. This group, consisting of 14 males and three females, were thought to have subclinical intestinal disease and formed the material for this study. The results are presented in Tables I and II and Fig. 2.

Relation to Hypoalbuminaemia.-An incidence of hypoalbuminaemia of the order of $76 \%$ in the subjects tested as compared with $38 \%$ in the general population was the most striking finding in this study. Hypoalbuminaemia showed statistically significant positive correlations with impaired absorption of xylose $(x=16.45, P<0.01, r=0.4077)$ and folic acid $(x=14.20, P<0.01, r=0.3996)$ and with faecal fat excretion $(x=21.45, P<0.01, r=0.6242)$ though not with the severity of the histological changes $(x=0.46, P<0.10$, $r=0 \cdot 1893$ ). The results, therefore, strongly suggest that subnormal protein nutritional status may be a contributory factor

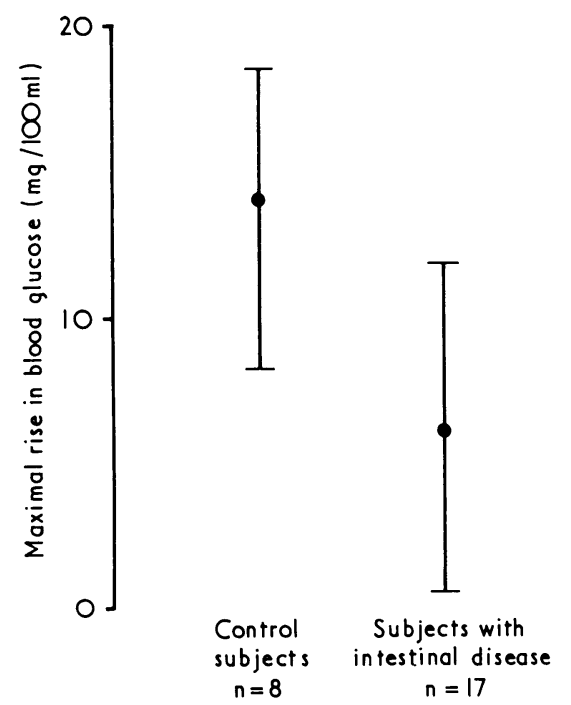

FIG. 2-Comparison of mean maximal rise in blood glucose over fasting level after $50-\mathrm{g}$ lactose ingestion
in control subjects and in subjects with intestinal in control

TABLE I-Serum Albumin Distribution in 50 Normal Control Subjects and in the 17 Subjects with Subclinical Intestinal Disease

\begin{tabular}{|c|c|c|}
\hline \multirow{2}{*}{$\begin{array}{l}\text { Serum Albumin } \\
\text { Levels }(\mathrm{g} / 100 \mathrm{ml})\end{array}$} & \multicolumn{2}{|c|}{$\%$ Distribution } \\
\hline & $\begin{array}{c}\text { Normal } \\
\text { Controls }\end{array}$ & $\begin{array}{l}\text { Subjects with } \\
\text { Malabsorption }\end{array}$ \\
\hline $\begin{array}{r}<2.9 \\
3.0 \\
>3.5\end{array}$ to 3.4 & $\begin{array}{l}13 \cdot 3 \\
24 \cdot 4 \\
62 \cdot 3\end{array}$ & $\begin{array}{l}29 \cdot 5 \\
47 \cdot 0 \\
23 \cdot 5\end{array}$ \\
\hline
\end{tabular}

in the causation of intestinal changes and absorptive defects in the subjects with subclinical intestinal disease. However, the study was inconclusive as regards the aetiology of hypoalbuminaemia in these subjects though. hepatocellular dysfunction could not be held responsible in view of the normal liver function tests and biopsies in those so tested.

Relation to Lactose Intolerance.-The results of lactose tolerance tests are shown in Fig. 2. Lactose malabsorption was found in every subject with subclinical intestinal disease, the peak rise in blood glucose above the fasting level varying from zero to $12.4 \mathrm{mg} / 100 \mathrm{ml}$ (mean $6.4 \mathrm{mg} / 100 \mathrm{ml}$ ) after a $50-\mathrm{g}$ oral test dose of lactose. On the other hand 8 of the 10 control subjects had flat tolerance curves, the maximal rise in blood glucose above the fasting level varying from 8.0 to 18.9 / $\mathrm{mg} / 100 \mathrm{ml}$ (mean $14.2 \mathrm{mg} / 100 \mathrm{ml}$ ), probably indicating therefore a lesser degree of mucosal enzyme deficency when compared with the subjects with subclinical malabsorption. Untoward symptoms of diarrhoea, bloating, or abdominal cramps often occurred in both groups. Thus lactose malabsorption was present in all the subjects with intestinal disease regardless of whether their serum albumin concentrations were depressed or normal. No correlation was found between lactose malabsorption and the intestinal capacity to absorb the other test substances. The significance of lactose malabsorption in the pathogenesis of intestinal disease remains unexplained, but seems aetiologically unimportant.

Relation to Parasitic Infestation.-The role of parasitic infestation in subclinical malabsorption was examined in relation to infestation with Strongyloides stercoralis and hookworm in four parasite-infested subjects with subclinical intestinal disease, and in none of these could the intestinal abnormalities be attributed to the presence of these parasites (Table II).

Relation to Anatomical Defects in Small Bowel.-The barium meal and follow-through radiological examination of eight subjects with subclinical intestinal disease showed no abnormality in any of them.

In summary of the accumulated data of this study it would seem that hypoalbuminaemia may be an important factor in the pathogenesis of subclinical intestinal disease as now defined in Nigerian subjects. Subnormal serum albumin levels occurred in 13 of the 17 subjects with intestinal disease. The four remaining subjects had normal serum albumin levels, so that intestinal disease in these subjects could not therefore be explained on the basis of protein deficiency. The possibility that the intestinal abnormalities observed in these subjects might be the "subclinical tropical sprue syndrome" which has been described by Klipstein and his associates forms part of the final inquiry into the aetiology of subclinical intestinal disease.

\section{Evaluation of Effects of Treatment}

In the second phase of studies into the aetiology of subclinical intestinal disease, the two factors-namely, hypoalbuminaemia and subclinical tropical sprue syndrome-were further examined by determining the therapeutic effects of protein and folic acid repletion and tetracycline therapy on

TABLE II-Effects of Deworming on Parasite Count, Xylose Absorption, and fejunal Biopsy in 4 Parasite-infested Subjects with Subclinical Intestinal Disease

\begin{tabular}{|c|c|c|c|c|c|c|c|}
\hline \multirow{2}{*}{ Subject No. } & \multirow{2}{*}{ Clinical Status } & \multicolumn{3}{|c|}{ Pre-deworming* } & \multicolumn{3}{|c|}{ Post-deworming $\dagger$} \\
\hline & & $\begin{array}{c}\text { Parasite } \\
\text { Count }\end{array}$ & $\begin{array}{c}\text { Xylose } \\
\text { Excretion }\end{array}$ & $\begin{array}{l}\text { Jejunal } \\
\text { Biopsy }\end{array}$ & $\begin{array}{c}\text { Parasite } \\
\text { Count }\end{array}$ & $\begin{array}{c}\text { Xylose } \\
\text { Excretion }\end{array}$ & $\begin{array}{l}\text { Jejunal } \\
\text { Biopsy }\end{array}$ \\
\hline 1 & $\begin{array}{l}\text { Subclinical intestinal disease plus } \\
\text { strongyloides infestion }\end{array}$ & \multirow{4}{*}{$\begin{array}{l}1,800 \text { larvae per } \\
\mathrm{g} \text { faeces } \\
4,600 \text { larvae per } \\
\mathrm{g} \text { faeces } \\
15,300 \text { ova per } \mathrm{g} \\
\text { faeces } \\
330 \text { ova per } \mathrm{g} \\
\text { faeces }\end{array}$} & $3.0 \mathrm{~g} / 5 \mathrm{hr}$ & $2+$ & \multirow{4}{*}{\begin{tabular}{c} 
Nil \\
Nil \\
650 ova per $\mathrm{g}$ \\
faeces Nil \\
\multicolumn{1}{c}{ Nil }
\end{tabular}} & $3 \cdot 2 \mathrm{~g} / 5 \mathrm{hr}$ & $2+$ \\
\hline 2 & " & & $4 \cdot 1 \mathrm{~g} / 5 \mathrm{hr}$ & $2+$ & & $4 \cdot 0 \mathrm{~g} / 5 \mathrm{hr}$ & $2+$ \\
\hline 4 & $\begin{array}{l}\text { Subclinical intestinal disease plus } \\
\text { hookworm infection }\end{array}$ & & $4 \cdot 2 \mathrm{~g} / 5 \mathrm{hr}$ & $1+$ & & $4.0 \mathrm{~g} / 5 \mathrm{hr}$ & $1+$ \\
\hline 13 & " & & $3.0 \mathrm{~g} / 5 \mathrm{hr}$ & $2+$ & & $3.5 \mathrm{~g} / 5 \mathrm{hr}$ & $2+$ \\
\hline
\end{tabular}

* Bephenium hydooxynaphthoate (Alcopar) $5 \mathrm{~g}$ alternate days $\times 3$ doses for hookworm infection. Dithiazanine iodide $100 \mathrm{mg}$ t.d.s. $\times 7$ for Strongyloides stercoralis infection.

* Bephenium hydooxynaphthoate (Alcopar) $5 \mathrm{~g}$ alternate days $\times$
+ Two to three weeks after completion of anthelmintic therapy. 
TABLE III-Aetiology of Subclinical Intestinal Disease: Changes in Biochemical, Haematological, and fejunal Biopsy Abnormalities with Protein and Folic Acid Repletion and Tetracycline Therapy in 8 Subjects with Intestinal Disease

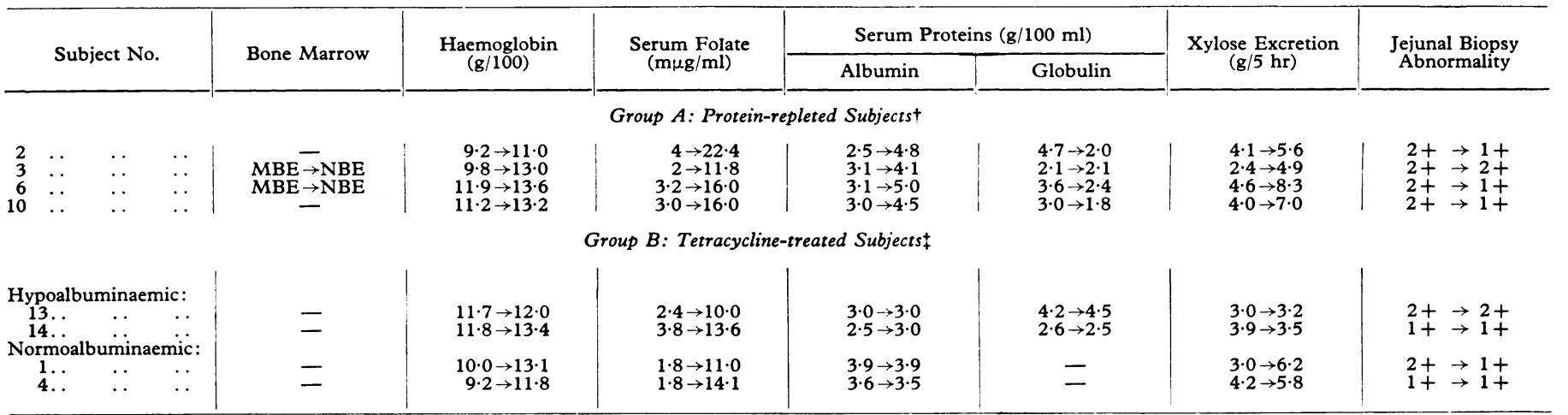

* All subjects had had $45 \mathrm{mg}$ parenteral sodium folate in the folic acid absorption test 4 weeks previously. + Intravenous aminofusin $4 \cdot 6$ pints $(2 \cdot 6$ litres $)(50 \mathrm{~g}$ amino-acid content $/ 500 \mathrm{ml})$. $\$ 750 \mathrm{mg}$ tetracycline daily for 3 weeks.

the existing haematological deficiencies and intestinal abnormalities in eight subjects in whom subclinical intestinal disease had been defined and who were available for continuation of the study. All the eight subjects had earlier received therapeutic doses of Folvite administered in the folic acid absorption test, and had become folate-repleted. It was argued that since the physiological requirement of folic acid is probably no more than $50 \mu \mathrm{g} /$ daily (Sheehy et al., 1961; Zalusky and Herbert, 1961; Druskin et al., 1962) it could be assumed that the saturation doses of parenteral sodium folate (Folvite) in the folic acid absorption test adequately corrected the deficiency of this vitamin in the eight subjects so tested within the period of reinvestigation.
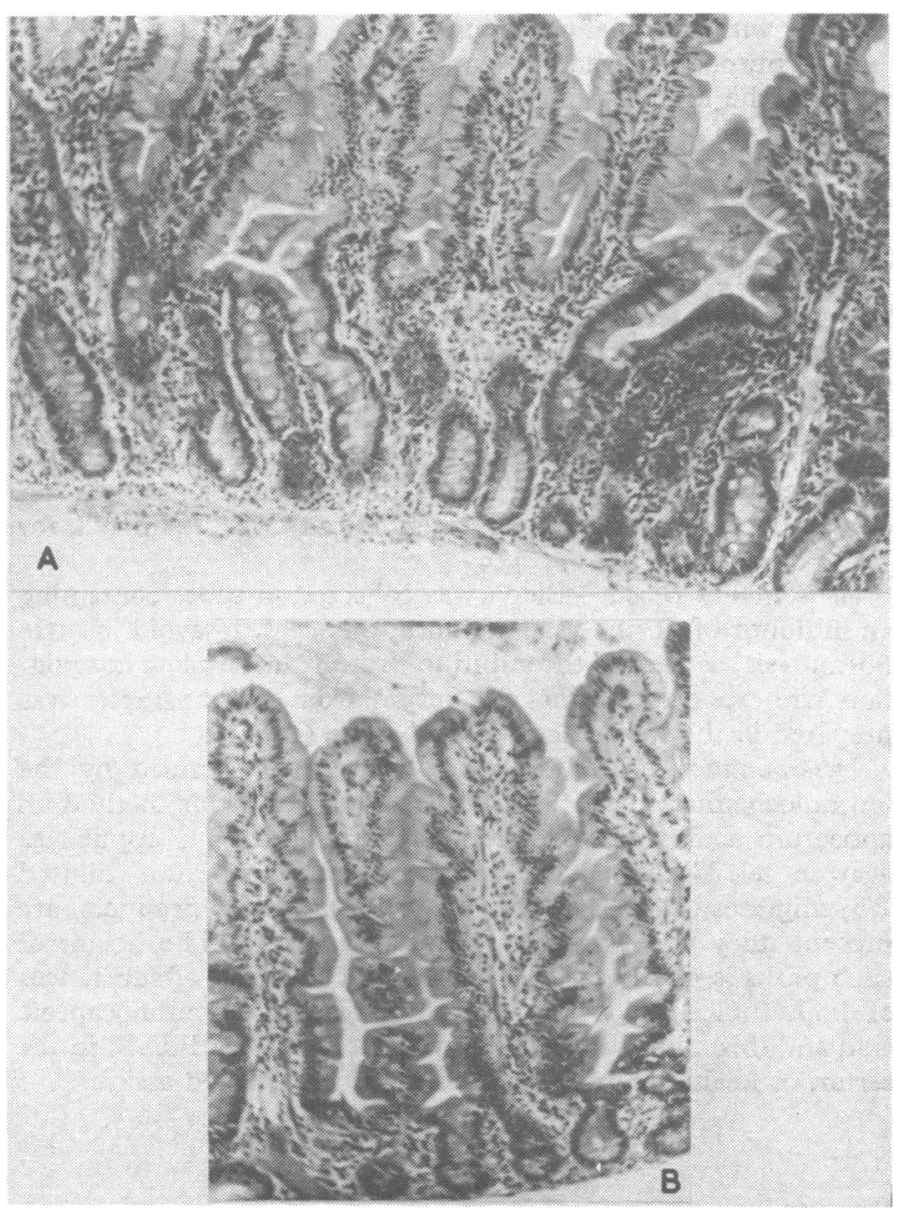

FIG. 3-Hypoalbuminaemic subject No. 10 (Table III). A, Pretreatmensmall-intestinal biopsy material showing $2+$ villous abnormality. B, Reversion to 1 + villous abnormality in biopsy material taken six weeks after folic acid and protein (Aminofusin) repletion therapy.
The subjects were grouped into two categories. The four subjects in group A all had subnormal albumin levels in the serum. Hypoalbuminaemia in them was adequately corrected with intravenous infusions of 2 pints $(1,140 \mathrm{ml})$ of Aminofusin solution given weekly for two to three weeks during a brief period in hospital. The group B subjects (two hypoalbuminaemic and two normoalbuminaemic) were treated with tetracycline $750 \mathrm{mg}$ daily for three weeks on an outpatient basis.

All the eight subjects were subsequently retested for possible structural changes in villi and in absorptive capacity for D-xylose, as well as changes in haematological status. The results are presented in Table III and Fig. 3.

The most striking findings of this part of the study concern the group A subjects, in all four of whom protein repletion resulted in rapid disappearance of xylose malabsorption, with dramatic return towards normal structure observed in intestinal biopsy material in three of the subjects (Table III and Fig. 3). It would seem therefore that the correction of protein and folate deficiencies was responsible for the restoration of anatomical and functional integrity of the small bowel in this group of subjects.

Surprisingly, however, the two folate-repleted, but hypoalbuminaemic subjects in group $\mathbf{B}$ who received tetracycline treatment only without Aminofusin infusion showed no significant changes in small-bowel morphology and function as a result of this therapy (Table III). This observation would suggest that protein deficiency is in fact the crucial factor in the pathogenesis of subclinical intestinal disease, since folate repletion alone in these subjects failed to correct the intestinal abnormalities. In contrast, the two normoalbuminaemic and folate-repleted subjects in group B, who also had tetracycline therapy, showed obvious histological and functional improvement. But the question of whether this improvement was due to antibiotic therapy per se or simply to the correction of folate deficiency in subjects who already had a normal protein nutritional status cannot be answered.

In conclusion, this investigation strongly points to hypoalbuminaemia as the important factor in the production of a biochemically and histologically defined malabsorptive state, leading to subnormal nutritional status, in asymptomatic indigenes of Nigeria.

I acknowledge the interest and help given by Professor A. E. Read, of Bristol; Professor Fred A. Klipstein, of Rochester, New York; Professor A. Mohiuddin, of the College of Medicine, University of Lagos; and Mr. S. O. Johnson, medical photographer.

\section{References}

Amini, F. (1963). Fournal of Tropical Medicine and Hygiene, 66, 190.

Baker, S. J., Ignatius, M., Mathan, V. I., Vaish, S. K., and Chacko, C. C. (1962).' In Intestinal Biopsy, Ciba Foundation Study Group, No. 14, p. 84. London, Churchill. 
Banwell, J. G., Hutt, M. S. R., and Tunnicliffe, R. (1964). East African Medical fournal, 41, 46

Banwell, J. G., Marsden, P. D., Blackman, V., Leonard, P. T., and Hutt, M. S. R. (1967). American Fournal of Tropical Medicine and Hygiene, 16,304 .

Burman, D. (1965). Archives of Diseases in Childhood, 40, 526.

Butterworth, C. E., and Perez-Santiago, E. (1958). Annals of Internal Medicine, 48, 8

Chacko, C. J. G., Job, C. K., Johnson, S., and Baker, S. J. (1961). Indian Fournal of Pathology and Bacteriology 4, 203.

Colwell, E. J., Welsh, J. D., Legters, L. J., and Proctor, R. F. (1968). fournal of the American Medical Association, 206, 2273.

Druskin, M. S., Wallen, M. H., and Bondgura, L. (1962). New England Fournal of Medicine, 267, 483.

Dyer, N. H., and Dawson, A. M. (1968). British Medical fournal, 2, 161, 225

England, W. N. J., and O'Brien, W. (1966). Gut, 7, 120.

Falaiye, J. M. (1969). West African Medical fournal, 18, 71

Falaiye, J. M. (1970). Journal of Tropical Medicine and Hygiene, 73, 119

Garcia, S. (1968). American Fournal of Clinical Nutrition, 21, 1066.

Gilles, H. M., Watson-Williams, E. J., and Ball, P. A. J. (1964). Quarterly Fournal of Medicine, 33, 1

Ingelfinger, F. J., et al. (1967). Federation Proceedings, 26, 1388.

Jeejebhoy, K. N., Desai, H. G., Moronha, J. M., Antia, F. P., and Parekh, D. V. (1966). Gastroenterology, 51, 333.

Klipstein, F A (1964) Gastroenterology, 47, 457

Klipstein, F. A., and Falaiye, J. M. (1969). Medicine, 48, 475.
Klipstein, F. A., Samloff, I. M., and Schenk, E. A. (1966). Annals of Internal Mecicine, 64, 575.

Leblond, C. P., and Messner, B. (1958). Anatomical Record, 132, 247.

Leblond, C. P., and Walker, B. E. (1956). Physiological Reviews, 36, 255

Lindenbaum, J. (1965). British Medical fournal, 2, 326.

Lindenbaum, J. (1968). American fournal of Clinical Nutrition, 21, 1023. Lindenba:1m, J., Jamiul Alam, A. K. M., and Kent, T. H. (1966a). British Medical fournal, 2, 1616.

Lindenbaum, J., Kent, T. H., and Sprinz, H. (1966b). Annals of Internal Medicine, 65,1201

Milner, P. F., Irvine, R. A., Barton, C. J., Bros, G., and Richards, R (1965). Gut, 6, 574.

Russel, P. K., Aziz, M. A., Ahmad, N., Kent, T. H., and Gangarosa, E. J. (1966). American fournal of Digestive Diseases, 11, 296.

Sheehy, T. W., Legters, J. J., and Wallace, D. K. (1968). American fournal of Clinical Nutrition, 21, 1013.

Sheehy, T. W., Rubini, M. E., Perez-Santiago, E., Santini, R., and Haddock, J. (1961). Blood, 18, 623 .

Sprinz, H., et al. (1962). American fournal of Clinical Pathology, 38, 43. Stanfield, J. P., Hutt, M. S. R., and Tunnecliffe, R. (1965). Lancet, 2 519.

Tandon, B. N., Das, B. C., Saraya, A. K., and Deo, M. G. (1966). British Medical fournal, 1, 714 .

Tandon, B. N., Das, B. C., Saraya, A. K., Ramachandran, K., and Sama, S. K. (1969). Gut, 10, 360.

Watson, W. C., Paton, E., and Murray, D. (1965). Lancet, 2, 47

Zalusky, R., and Herbert, V. (1961). New England fournal of Medicine, 365, 1033 .

\title{
Fibrin Degradation Products and Ovarian Tumours
}

\author{
B. ÅSTEDT, L. SVANBERG， I. M. NILSSON
}

British Medical fournal, 1971, 4, 458-459

\section{Summary}

Fibrin degradation products (F.D.P.) were determined in the serum of 163 women in whom ovarian tumours had been suspected on palpation at gynaecological examination and who were afterwards examined by laparoscopy or subjected to laparotomy. F.D.P. were found in the serum $(0.5-30 \mathrm{mg} / 100 \mathrm{ml})$ of $23(72 \%)$ out of 32 patients with malignant tumours. Of 131 patients with benign findings F.D.P. (traces to $2 \mathrm{mg} / 100 \mathrm{ml}$ ) were found in six $(4.5 \%)$, and in most of these the occurrence of F.D.P. could be explained on other clinical grounds. The findings suggest that the examination of F.D.P. in suspected malignant ovarian tumour may be of diagnostic value.

Determination of F.D.P. in malignant ascitic fluid showed very high values, ranging between 40 and $350 \mathrm{mg}$ / $100 \mathrm{ml}$. This argues for the occurrence of F.D.P. in the blood being due to an extravascular breakdown of fibrin caused by tumour cells, but they may also be due to thromboplastic and fibrinolytic agents from the tumour entering the blood stream.

\section{Introduction}

Malignant tumours have coagulative properties (O'Meara, 1958) and their vascularization and growth require a fibrin network as a matrix (see Laki and Yancey, 1968). A neoplasm may also possess fibrinolytic activity (Cliffton and Grossi, 1955; Thornes, 1967; Peterson et al., 1968; Davidson et al., 1969; Böck et al., 1970). The activity of such coagulative and fibrinolytic processes during tumour growth may be reflected by fibrin degradation products (F.D.P.) in the blood. Merskey et al. (1966) and

Allmănna Sjukhuset, Malmø, Sweden

B. ASTEDT, M.D., Senior Gynaecologist

L. SVANBERG, M.D., Senior Gynaecologist

I. M. NILSSON, M.D., Professor of Medicine
Colman et al. (1970) reported the occurrence of F.D.P. in the serum of some patients with malignant diseases. Hedner and Nilsson (1971) found F.D.P. in the serum of $61 \%$ of 162 patients with malignant tumours.

The purpose of the present investigation was to find out whether the finding of F.D.P. might be of diagnostic value in patients with clinically suspect ovarian tumour.

\section{Patients and Methods}

The clinical material consisted of 163 women in whom palpation at gynaecological examination gave reason to suspect ovarian tumours. Blood samples were obtained for determination of F.D.P. The patients were afterwards examined by laparoscopy or subjected to laparotomy. Biopsy specimens and operative specimens were afterwards examined histologically and classified. Also ascitic fluid, when found, was examined for F.D.P.

Collection of Blood.-Blood was collected in tubes containing an inhibitor of fibrinolysis, aminocaproic acid, to avoid in-vitro fibrinolysis, as well as thrombin to prevent incomplete coagulation with residual fibrinogen. Serum from these samples was prepared in the way described by Niléhn (1967).

Determination of F.D.P.-F.D.P. were determined by the immunochemical method of Niléhn (1967). In this method an antiserum against the D-fraction of the F.D.P. is applied to agarose gel. With high-voltage electrophoresis serum (diluted $1 / 5$ ) migrates into the gel. If F.D.P. (X, Y, or D products) are present, they will produce precipitation peaks. The height of such peaks is measured and related to a standard of substances of high molecular weight. In the presence of aminocaproic acid and thrombin this method will not show any F.D.P. in the serum of healthy control women, even in repeated assays.

\section{Results}

Of the 163 women examined 32 were found to have malignant tumours. In the remaining 131 the lesions were benign. Of the 